\title{
Young Honeybee (Apis mellifera bandasii) Queens Perform Better than Old Ones
}

\author{
Zewdu Ararso Hora*, Gemechis Legesse Yadeta, Tadele Alemu Hundie \\ Holeta Bee Research Center, Oromia Agricultural Research Institute, Holeta, Ethiopia \\ Email address: \\ zewdu402@yahoo.com (Z. A. Hora),glegesseyadeta@gmail.com (G. L. Yadeta), alemut34@gmail.com (T. A. Hundie) \\ ${ }^{*}$ Corresponding author
}

\section{To cite this article:}

Zewdu Ararso Hora, Gemechis Legesse Yadeta, Tadele Alemu Hundie. Young Honeybee (Apis mellifera bandasii) Queens Perform Better than Old Ones. American Journal of Life Sciences. Vol. 7, No. 6, 2019, pp. 128-132. doi: 10.11648/j.ajls.20190706.15

Received: October 5 2019; Accepted: December 16, 2019; Published: December 24, 2019

\begin{abstract}
A productivity of queen bee depends on several factors. Queen age is one of the most important factors affecting queen's, as well as colony performance. The study was conducted to determine the effects of queen ages on performances of honeybee (Apis mellifera) colonies. The queens were reared from local honeybee, Apis mellifera bandasii (A. m. bandasii); nuclei colonies were formed and then transferred to standard Langstroth hives when all the frames of the nuclei boxes were occupied with brood and adult bees. Performances of the colonies headed by the new queens were evaluated over three years. Brood area, number of queen cell cups started and swarm queen cells constructed, number of empty cells/100 cells/per colony (brood solidness) and honey yield per harvest were determined every active season for three consecutive years. Colonies headed by 1-, 2- and 3-year-old queens produced $4721.43 \pm 511.85,5523.08 \pm 490.07$ and $3433.82 \pm 413.83 \mathrm{~cm}^{2}$ sealed brood, and constructed $0.07 \pm 0.07,2.23 \pm 0.52$ and $9.90 \pm 1.89$ queen cell cups and swarm cells/colony with $1.86 \pm 0.38,2.40 \pm 1.65$ and $8.85 \pm 2.52$ empty cells/100 cells/per colony, respectively. Honey harvested from 1- and 3-year-old queen colonies averaged $13.34 \pm 1.11$ and $10.50 \pm 2.04 \mathrm{~kg} /$ colony/harvest, respectively. The colonies headed by 1 -, and 2 -year-old queens had more brood areas, better brood solidity, less number of queen cells but no significant differences in honey production compared to colonies headed by 3 -year-old queens. Our results indicate that queen age has a significant effect on colony performances, suggesting that requeening every three years is adequate for our local honeybee colonies.
\end{abstract}

Keywords: Apis mellifera, Queen Age, Brood Rearing, Swarm Queen Cells, Queen Cell Cups

\section{Introduction}

A productivity of queen bee depends on several factors. Queen age is one of the most important factors affecting queen quality $[1,2]$ that influences brood production, colony growth rate and productivity of the colonies [3]. It is commonly accepted that the queen bee maintains its productivity only for a limited time of her lifespan, which may remain from one to four years in different climates [4]. As the queen bees get older and older, their laying ration could decrease and they may lay more unfertilized eggs than young queens. Moreover, when queens get old, they start to produce insufficient queen pheromones [5]. The lesser the amount of queen pheromones in turn affect queens' attraction to workers [6] and queens' power to inhibit building of swarm queen cells [7], which can reduce colonies productive performances.

Different studies conducted in temperate climates of England, New Zealand and Poland, revealed that colonies headed by a year old queens have shown better performance than those head by two years old queens [8-10]. Moreover, a study conducted in Israel (under subtropical condition) found that colonies headed by 7 to 10 -months-old queens had higher brood areas, constructed less swarm queen cells and produced more honey than those headed by up 20-month-old queens during nectar flow season [11]. As a result, yearly requeening of a colony in commercial apiaries has been implemented as a routine practice in countries like Israel [11], as queen's reproductive physiology is greatly affected by the climatic conditions of an area where the honeybee colonies kept [12].

Apart from climatic conditions, the efficient reproductive lifespan of queen bees could be affected by the nectar and 
pollen flow and resource fullness of an area. To this effect, queens in the areas with constant flow of resources and with a high constant rate of egg laying can get exhausted after year [13]. Moreover, it has been indicated that queens in the resource rich areas where the environmental conditions allow full activities of the colonies for a longer period of a year, lay eggs rapidly through the whole season [5]. Under this situation, the queens may get exhausted soon and become less efficient in heading the large colonies in short period of time as opposed to those queens in longer dearth period areas. Despite all the aforementioned studies on the performances of colonies headed by queens of different ages under different environmental conditions elsewhere, there is no quantitative data on the effects of honeybee queen's age on the performances of Ethiopian local honeybee colonies. Therefore, the aim of this work was to determine the effect of queen's age on the performances of local honeybee colonies, such as brood population, brood solidness, queen cups and swarm queen cells, and honey production under central highland condition of Ethiopia.

\section{Materials and Methods}

\subsection{Description of the Study Area}

The study was conducted at the experimental Apiary of Holeta Bee Research Center in Oromia Regional State of Ethiopia. The apiary is located in central highlands of Ethiopia at $9^{\circ} 30^{\prime} \mathrm{N}$ and $38^{\circ} 30^{\prime} \mathrm{E}, 2450 \mathrm{~m}$ above sea level and $30 \mathrm{~km}$ west of Addis Ababa. The annual mean temperature of the site is $14^{\circ} \mathrm{C}$ with May the hottest month (mean temperature $23.8^{\circ} \mathrm{C}$ ) and December the coldest month (mean temperature $1.7^{\circ} \mathrm{C}$ ). The annual mean rainfall is 1060 $\mathrm{mm}$ with an average relative humidity of $58 \%$. The vegetation around Holeta is characterized by bush lands, numerous herbaceous and grass floras, scattered trees and planted eucalyptus trees, cultivated oil and horticultural crops.

\subsection{Establishing Experimental Colonies}

Central highland local honeybee (A. m. bandasii) colonies were obtained from local beekeepers around Holeta, and kept in standard Langstroth hives with 10 frames for colony buildup at the apiary of Holeta Bee Research Center during the active season (September to November).

Honeybee queens were reared using grafting method from the stock established during the second breeding season (in May). Five frame nuclei colonies with two frames of emerging bees, two frames of honey and one frame pollen were formed, as described elsewhere [14]. Then, newly hatched virgin queens in queen cages were given to all nuclei colonies. A day later the virgin queens were released from their cages and left for open mating. Three weeks later queens were checked for their egg laying and queens started egg laying were marked on their thorax with number codes. Nuclei colonies were transferred to standard Langstroth hives when the bees occupied all the frames of the nuclei boxes.
Prior to the beginning of the study, colonies were subjectively estimated for their strength based on areas of combs covered by adult bees, brood, nectar and honey, and pollen, as described elsewhere [15]. Then, 15 colonies with similar strength were selected as the experimental colonies. All the necessary management practices were done to the colonies.

\subsection{Measuring Colony Performance}

The following variables were monitored every active season using an objective mode which uses empirical measures:

Brood area: the area occupied by immature worker honeybees (eggs + larvae + capped brood) in colonies was evaluated every 21 days by overlaying a grid pre-marked in 5 $\mathrm{cm}$ by $5 \mathrm{~cm}$ on each sides of every brood frame and the area covered with the brood was visually summed [16].

Brood pattern (solidness): the degree of worker brood solidity was determined using a piece of cardboard with a rhombus equals in size to $10 \times 10$ cells was laid over a section of sealed brood and number of empty cells within the section was counted. This measure was repeated on different patches of brood frames to obtain a mean of at least 10 observations [15].

Queen cell production: swarming tendency of the colonies was verified once every two weeks. All brood frames in each colony were carefully inspected and all queen cell cups and swarm queen cells were counted and destroyed to prevent swarming and duplicate observations [15].

Honey yield: harvested honey yield was measured as a difference between weight of honey frames before and after honey extraction. Honey combs remained for a colony as a reserve food were not included in this honey yield estimation.

Statistical analysis: statistical tests were conducted using SAS software (version 9.0, SAS Institute Inc.) at the 0.05 level of significance. Variables were analyzed using general linear model (GLM). When a significant effect was observed $(p<0.05)$, the means of the experimental groups were compared using Tukey-Kramer grouping's least significant difference method.

\section{Results and Discussion}

\subsection{The Effect of Queens'Age on Brood Production}

The average brood area of queens with different age groups is depicted in Table 1. We found no significant differences in brood production among 1-, and 2-year-old queens $(p>0.05)$. However, the decline of brood production in colonies headed by older queens were apparent during the third year, when they produced significantly less brood than 1 - and 2-year-old queens $(p<0.05)$, indicating that 1 - and 2year-old queens were more prolific than 3 -year-old queens. Our result with older queens is in agreement with the previous reports that brood production of a queen decrease with increasing age of the queen [3, 10, 11, 17, 18], suggesting that colonies headed by young queens had a 
greater brood area compared to colonies headed by old queens. Thus, the current result indicates that queen age may be among the important elements that affect brood production performance of a colony and also needs due attention during making management decisions based on whether a queen is judged to be good or failing.

\subsection{The Effect of Queens'Age on Construction of Queen Cups and Swarm Queen Cells}

The average number of queen cups and swarm queen cells constructed in colonies headed by 3 -year-old queens was 4.46 times higher than 2-year-old queens, and 141.43 times more than 1-year-old queens (Table 1). This results reveal that colonies headed by old queens constructed significantly more queen cups and swarm queen cells compared to young queens $(p<0.01)$. Noticeably, the fact that we found more number of queen cups and swarm queen cells in colonies headed by old queens than those headed by young queens may reflect the substantial effect of queen's age on the constructions of queen cups and swarm queen cells [11]. It has indeed been reported by several studies that colonies with older queens have a higher swarming tendency $[9,11,19$ 21]. This stronger inclination to swarm in colonies headed by old queens suggests that the age of queen bees affect both their attractiveness [6] and power to inhibit building of queen cups and swarm queen cells [7]. Other than the queen's age, a strong relationship between brood area, and construction of queen cups and swarm queen cells has been reported under $[7,22]$. We analyzed the correlation between the construction of queen cups and swarm queen cells, and that of brood area during the study period. The weak correlation $(\mathrm{r}=0.21$; $p=0.09$ ) between brood area, and queen cups and swarm queen cells suggests that brood area has less effect on the construction of queen cups and swarm queen cells in uncongested colonies [11], as our experimental colonies were provided with extra hive volume to prevent swarming, which was achieved by placing additional supers that were only partially occupied by workers. These findings clearly highlight the construction of queen cups and swarm queen cells might be due to the changes occurred in the queen bees with their ages [6].

Table 1. The effects of queen ages on brood production, construction of queen cups and swarm queen cells, brood solidness and honey yield.

\begin{tabular}{llll}
\hline Queen's age & Brood area $\left(\mathbf{c m}^{2} /\right.$ colony) & $\begin{array}{l}\text { Number of queen cups and } \\
\text { swarm cells/colony/season }\end{array}$ & $\begin{array}{l}\text { Number of empty cells/100 } \\
\text { cells }\end{array}$ \\
\hline 1-year-old & $4721.43 \pm 511.85^{\text {ab }}$ & $0.07 \pm 0.07^{\mathrm{b}}$ & $\begin{array}{l}\text { Honey yield/colony/harvest } \\
(\mathbf{k g})\end{array}$ \\
2-year-old & $5523.08 \pm 490.07^{\mathrm{a}}$ & $2.23 \pm 0.52^{\mathrm{b}}$ & $2.40 \pm 0.38^{\mathrm{b}}$ \\
3-year-old & $3433.82 \pm 413.83^{\mathrm{b}}$ & $9.90 \pm 1.89^{\mathrm{a}}$ & $8.85 \pm 2.52^{\mathrm{a}}$ \\
\hline
\end{tabular}

Averages assigned the same letters do not significantly differ at $p<0.05$.

\subsection{The Effect of Queen's Age on Brood Pattern}

Brood pattern quality, which is meant the degree of worker brood solidity, is one of the general measures that indicates either the queen is not laying eggs well or the developing bees are not surviving to eclosion $[23,24]$. In this study, we found that brood solidity in colonies headed by 1-, and 2-year-old queens were significantly $(p<0.01)$ elevated than those headed by 3 -year-old queens (Table 1), confirming that brood pattern quality of young and old queens were different. A better brood pattern, as indicated by solid patches of capped brood in colonies headed by young queens, designates young queens are laying viable eggs which are developing into healthy larval and pupal bees [25], which can significantly reduce the risk of colony mortality due to poor brood pattern [24]. On the contrary, the higher number of empty cells $(>7 \%)$ in colonies headed by 3 -year-old queens is a reliable indicator of poor brood patter, which suggests that the quality of the queen is falling [26]. Our result emphasizes that as age of a queen increases, brood solidity deceases, indicating that brood solidity is among the various metrics to be considered to make management decision whether a queen is judged to be good or failing.

\subsection{The Effect of Queen's Age on Honey Yields}

During the second year of the experiment, there was a heavy rainfall just three weeks ahead of the expected honey harvesting time for the area. As a result, there was no enough honey yield data collected for 2-year-old queens. The colonies from the first and third year (headed by 1- and 3year-old queens, respectively) produced average honey yield of $13.34 \pm 1.11$ and $10.50 \pm 2.04 \mathrm{~kg} /$ colony/harvest, respectively (Table 1). Differences among the group means of honey yield were not significant $(p>0.19)$. Although there were no significant variations among colonies headed by queens of different ages, colonies headed by 1 -year-old queens gave higher amount of honey yield, approximately $27 \%$ times more honey than that produced by colonies headed by 3-year-old queens. Regarding honey yield of colonies with young queens, previous studies have provided contradictory results. Some of them have reported that colonies headed by young queens performed better than colonies with old queens $[3,11$, 27, 28], whereas others have found non-significant differences in honey production between such colonies [17, 29]. Our current result is in agreement with what has been concluded by the latter authors. The insignificant variations in honey yields of colonies headed by 1-year-old queens from colonies headed by 3 -year-old queens might be attributed to the regular removal of swarm queen cells in the latter group, that might reduce the negative effect of swarm issuing on honey yield [9].

\section{Conclusion}

The present data provide detailed insight into the reasons 
for differences in overall colony performance and honey production among local honeybee $(A$. $m$. bandasii) colonies headed with queens of different ages. Colonies with queens 3 -year-old produced less brood with relatively poor brood pattern, and more queen cups and swarm queen cells than colonies with queens 1-year-old or 2-year-old, but the honey yield is not significantly different. Yet, local honeybee colonies headed by 1-year-old queens gave higher amount of honey yield, approximately $27 \%$ times more honey than that produced by colonies headed by 3-year-old queens. Therefore, it is very important to requeen $A$. m. bandasii colonies of central highland of Ethiopia every three years to have colonies with populous brood, better brood pattern, less queen cups and swarm queen cells, and better honey yield under local conditions with two active seasons.

\section{Acknowledgements}

We would like to express our deep appreciation to Oromia Agricultural Research Institute (OARI) for financial support for the research. A special thanks to the technical staffs, in particular Mr. Terefe Chimdi for his help during data collection.

\section{References}

[1] Cengiz M, Emsen B, Dodologlu A. Some characteristics of queenbees (Apis mellifera L.) rearing in queenright and queenless colonies. J Anim Vet Adv. 2009; 8: 1083-1085.

[2] Invernizzi C, Harriet J, Carvalho S. Evaluation of different queen introduction methods in honeybee colonies in Uruguay. Apiact. 2006; 41: 1-20.

[3] Akyol E, Yeninar H, Karatepe M, Karatepe B, Özkök D. Effects of queen ages on Varroa (Varroa destructor) infestation level in honey bee (Apis mellifera caucasica) colonies and colony performance. Ital J Anim Sci. 2007; 6: 143-149. doi: 10.4081/ijas.2007.143.

[4] Seeley TD. Life History Strategy of the Honey Bee, Apis mellifera. Oecologia. 1978; 32: 109-118.

[5] Crane E. Bees and beekeeping: Science, practice and world resources. Oxford: Heinemann Newnes; 1990.

[6] De Hazan M, Lensky Y, Cassier P. Effects of queen honeybee (Apis mellifera L.) ageing on her attractiveness to workers. Comp Biochem Physiol Part A Physiol. 1989; 93: 777-783. doi: 10.1016/0300-9629(89)90501-X.

[7] Lensky Y, Slabezki Y. The inhibiting effect of the queen bee (Apis mellfer L.) foot-print pheromone on the construction of swarming queen cups. J Insect Physiol. 1981; 27: 313-323. doi: 10.1016/0022-1910(81)90077-9.

[8] Simpson J. Variation in the incidence of swarming among colonies of Apis mellifera throughout the summer. Insectes Soc. 1959; 6: 85-99.

[9] Forster IW. Swarm Control in Honey Bee Colonies. New Zeal J Agric Res. 1969; 12: 605-610. doi: $10.1080 / 00288233.1969 .10421245$.
[10] Hatjina F, Costa C, Büchler R, Uzunov A, Drazic M, Filipi J, et al. Population dynamics of European honey bee genotypes under sdifferent environmental conditions. J Apic Res. 2014; 53: 233-247. doi: 10.3896/IBRA.1.53.2.05.

[11] Hauser H, Lensky Y. The effect of the age of the honey bee (Apis mellifera L) queen on worker population, swarming and honey yields in a subtropical climate. Apidologie. 1994; 25: 566-578. doi: 10.1051/apido:19940607.

[12] Rangel J, Böröczky K, Schal C, Tarpy DR. Honey Bee (Apis mellifera) Queen Reproductive Potential Affects Queen Mandibular Gland Pheromone Composition and Worker Retinue Response. PLoS One. 2016; 11: e0156027. doi: 10.1371/journal.pone.0156027.

[13] Furgala B, McCutcheon DM. Wintering productive colonies. In: Graham JM, editor. The hive and the honey bee. Hamilton, Illinois: Dadant \& Sons; 1992. pp. 829-868.

[14] Akyol E, Kaftanoglu O. Colony characteristics and the performance of Caucasian (Apis mellifera caucasica) and Mugla (Apis mellifera anatoliaca) bees and their reciprocal crosses. J Apic Res. 2001; 40: 11-15.

[15] Delaplane KS, Steen J van der, Guzman-Novoa E. Standard methods for estimating strength parameters of Apis mellifera colonies. In: Dietemann V, Ellis JD, Neumann P, editors. The COLOSS BEEBOOK, Volume I: standard methods for Apis mellifera research. Journal of Apicultural Research 52 (1); 2013. pp. 1-12. doi: 10.3896/IBRA/1.52.1.03.

[16] Maucourt S, Fournier V, Giovenazzo P. Comparison of three methods to multiply honey bee (Apis mellifera) colonies. Apidologie. 2018; 49: 314-324. doi: 10.1007/s13592-0170556-9.

[17] Kostarelou-Damianidou M, Thrasyvoulou A, Tselios D, Bladenopoulos K. Brood and honey production of honey bee colonies requeened at various frequencies. J Apic Res. 1995; 34: 9-14. doi: 10.1080/00218839.1995.11100880.

[18] Akyol E, Yeninar H, Korkmaz A, Çakmak İ, Akyol E, Yeninar $\mathrm{H}$, et al. An observation study on the effects of queen age on some characteristics of honey bee colonies. Ital J Anim Sci. 2008; 7: 19-25. doi: 10.4081/ijas.2008.19.

[19] Winston ML. The Biology of the Honey Bee. Cambridge, London: Harvard University Press; 1987. doi: 10.1002/9780470114735.hawley00624.

[20] Uzunov A, Costa C, Panasiuk B, Meixner M, Kryger P, Hatjina F, et al. Swarming, defensive and hygienic behaviour in honey bee colonies of different genetic origin in a panEuropean experiment. J Apic Res. 2014; 53: 248-260. doi: 10.3896/IBRA.1.53.2.06.

[21] Uzunov A. Biological and productive characteristics of native honey bee (Apis mellifera macedonica) on the territory of Republic of Macedonia, PhD thesis. Faculty for Agricultural Sciences and Food. Skopje, Macedonia; 2013.

[22] Simpson J. The age of queen honeybees and the tendency of their colonies to swarm. J Agric Sci. Queen Mary, University of London; 1960; 54: 195. doi: 10.1017/s002185960002236x.

[23] Woyke J. Effect of Sex Allele Homo-Heterozygosity on Honeybee Colony Populations and on their Honey Production 1. Favourable Development Conditions and Unrestricted Queens. J Apic Res. 1981; 20: 148-155. doi: 10.1080/00218839.1980.11099997. 
[24] Lee K V., Goblirsch M, McDermott E, Tarpy DR, Spivak M. Is the Brood Pattern within a Honey Bee Colony a Reliable Indicator of Queen Quality? Insects. 2019; 10: 12. doi: 10.3390/insects10010012.

[25] VanEngelsdorp D, Tarpy DR, Lengerich EJ, Pettis JS. Idiopathic brood disease syndrome and queen events as precursors of colony mortality in migratory beekeeping operations in the eastern United States. Prev Vet Med. Elsevier B. V.; 2013; 108: 225-233. doi: 10.1016/j.prevetmed.2012.08.004.

[26] Laidlaw HH. Cotemporary Queen rearing. Hamilton, Illinois: Dadant and Sons Inc.; 1979. p. 199.
[27] Woyke J. Correlations and interactions between population, length of worker life and honey production by honeybees in a temperate region. J Apic Res. 1984; 23: 148-156. doi: 10.1080/00218839.1984.11100624.

[28] Guler A, Kaftanoglu O. Determination of Performances Some Important Races and Ecotypes of Turkish Honeybees (Apis mellifera L.) Under Migratory Beekeeping Conditions. Tr J Vet Anim Sci. 1999; 23: 577-581.

[29] Szabo TI, Lefkovitch LP. Effect of brood production and population size on honey production of honeybee colonies in Alberta, Canada. Apidologie. 1989; 20: 157-163. doi: 10.1051/apido:19890206. 